\title{
Commentary
}

\section{Promising Antiviral Molecules from Ayurvedic Herbs and Spices against COVID-19}

\author{
Mariappan Rajan ${ }^{1}$, Prashant Gupta², and Awanish Kumar ${ }^{3}$
}

COVID-19 is caused by the novel coronavirus severe acute respiratory syndrome coronavirus-2 (SARS-CoV-2) and smashed our society severely. Many efforts/measures have been taken worldwide to control coronavirus disease 2019 (COVID-19) but it is spreading ceaselessly across the globe. $^{(1)}$ Interestingly, Chinese medicine was used to treat COVID-19 and they found better recovery results. ${ }^{(2,3)}$ This has also drawn the attention of the scientific community to Ayurveda where traditional knowledge of this domain can be explored for finding COVID-19 a cure or prevention.

This technical note provides a first-round result that has been done at the interface of Ayurveda and in silico biology regarding COVID-19. This article aims to provide the readers an understanding of the basic principles of ancient medicine and conjugation of in silico technology in Ayurveda for the development of core concepts of Ayurveda. Quick screening of traditional herbs/spices phytoconstituents can be done by in silico study in polyherbal/Ayurvedic formulations. This inhibition/induction of phytoconstituents with target protein can quickly be identified by in silico study. ${ }^{(4,5)}$ Therefore, the authors have selected 11 herbs (Allium sativum, Cinnamomum cassia, Cuminum cyminum, Piper nigrum, Curcuma longa, Ocimum sanctum, Zingiber officinale, Coriandrum sativum, Syzygium aromaticum, Trachyaspermum ammi, Mentha arvensis) advised commonly in Ayurveda for in silico screening as an antimicrobial agent (Table 1). Total 26 major compounds were docked using AutoDock 4.2 simulator with the active site of the crystal structure of SARS-CoV-2 virus main protease (PDB ID: 6LU7, Table 1). Cinnzaylanol, cinnzeylanine, apigenin, and isobiflorin observed higher binding constant and inhibition activity against protease (PDB ID: 6LU7) denote a good antiviral property. The role and participation of protease in the endocytosis of SARS-CoV-2 into human cells are well established and they help in viral spread/infection in the host. ${ }^{(6)}$ Although this study was conducted with some individual compounds of ayurvedic herbs/spices to see the interaction and inhibitory properties with SARSCoV-2 protease. But routinely, herbs are advised to take collectively as a decoction (hot water extract of herbs), multiple phytoconstituents in the decoction formulation may synergize the inhibition results through single or multiple target sites. Further research is solicited for phytoconstituents interactions and their collective binding/inhibition behaviour against SARS-CoV-2 active sites. A docking study suggested that molecules of spices like curcumin and nimbin exhibited high interaction with SARS-CoV-2 target proteins viz., spike glycoprotein (MolDock score -141.36 and -148.62 kcal/mol) and angiotensin-converting enzyme 2 (ACE-2) receptor (MolDock score -142.64 and $-140.10 \mathrm{kcal} / \mathrm{mol}){ }^{(7)}$ The above data pave a way for further research to extend the use of self-care advisory given by the Indian AYUSH ministry in prophylaxis and management of hotspot area, vulnerable, COVID-19 warriors, confirm positive contacts, and cases under home quarantine/isolation centers.

Since no medicine is available for COVID-19, therefore, we should rely on those things that have antiviral acreage, immune-boosting, and anti-inflammatory properties with fewer side effects and commonly available for all. In this regard, herbs/spices selected in this study provided its satisfactory anti-COVID-19 property. As per literature, they have also immune-boosting, and anti-inflammatory properties. ${ }^{(5,8)}$ At a time when the world is reeling under the effects of COVID-19, the result of the study indicated that these Ayurvedic herbs/ spices should be looked as food therapeutics to protect individuals from various diseases. This is a short technical note and length does not permit to cover whole issues. The aim of the work is to simply attract/think researcher in this direction and to motivation for those who are working at the

(C)The Chinese Journal of Integrated Traditional and Western Medicine Press and Springer-Verlag GmbH Germany, part of Springer Nature 2021

1. Department of Natural Product Chemistry, Madurai Kamaraj University, Madurai-625021 (TN), India; 2. Department of Balroga, Shri NPA Govt. Ayurveda College, Raipur-492010 (CG), India; 3. Department of Biotechnology, National Institute of Technology, Raipur-492010 (CG), India

Correspondence to: Assistant Prof. Awanish Kumar, E-mail: drawanishkr@gmail.com

DOI: https://doi.org/10.1007/s11655-021-3331-8 
Table 1. Binding and Inhibition Activity of Ayurvedic Herbs/Spices Phytoconstituents with Target Protease (PDB ID: 6LU7) of SARS-CoV-2

\begin{tabular}{|c|c|c|c|c|}
\hline S. N. & Name of natural compound & Binding energy & Inhibition constant & Natural source (plant name) \\
\hline 1 & Allicin & -3.37 & $3.38 \mathrm{mmol} / \mathrm{L}$ & \multirow{3}{*}{ Allium sativum } \\
\hline 2 & Allyl disulfide & -2.68 & $10.90 \mathrm{mmol} / \mathrm{L}$ & \\
\hline 3 & Allyl trisulfide & -2.83 & $8.41 \mathrm{mmol} / \mathrm{L}$ & \\
\hline 4 & Cinnamaldehyde & -4.16 & $893.38 \mu \mathrm{mol} / \mathrm{L}$ & \multirow{3}{*}{ Cinnamomum cassia (Cinnamon) } \\
\hline 5 & Cinnazaylanol & -5.29 & $132.45 \mu \mathrm{mol} / \mathrm{L}$ & \\
\hline 6 & Cinnazaylanine & -5.12 & $178.04 \mu \mathrm{mol} / \mathrm{L}$ & \\
\hline 7 & 2-Ethyl-6-heptylphenol & -3.38 & $3.30 \mathrm{mmol} / \mathrm{L}$ & \multirow{3}{*}{ Cuminum cyminum } \\
\hline 8 & Cumenaldehyde & -4.5 & $506.19 \mu \mathrm{mol} / \mathrm{L}$ & \\
\hline 9 & Cymene & -3.95 & $1.27 \mathrm{mmol} / \mathrm{L}$ & \\
\hline 10 & Piperine & -4.94 & $240.08 \mu \mathrm{mol} / \mathrm{L}$ & Piper nigrum \\
\hline 11 & Bis demethoxycurcumin & -4.57 & $444.32 \mu \mathrm{mol} / \mathrm{L}$ & \multirow{2}{*}{ Curcuma longa } \\
\hline 12 & Curcumin & -3.36 & $3.44 \mathrm{mmol} / \mathrm{L}$ & \\
\hline 13 & 1,2-Dimethoxy-4-prop-1-enylbenzene & -4.53 & $476.06 \mu \mathrm{mol} / \mathrm{L}$ & \multirow{3}{*}{ Ocimum sanctum } \\
\hline 14 & Apigenin & -5.27 & $139.94 \mu \mathrm{mol} / \mathrm{L}$ & \\
\hline 15 & Eugenol & -4.9 & $255.14 \mu \mathrm{mol} / \mathrm{L}$ & \\
\hline 16 & Beta sitosterol & -4.1 & $987.25 \mu \mathrm{mol} / \mathrm{L}$ & \multirow{4}{*}{ Zingiber officinale } \\
\hline 17 & Gingerol & -2.72 & $10.06 \mathrm{mmol} / \mathrm{L}$ & \\
\hline 18 & Shagoals & -3.14 & $4.99 \mathrm{mmol} / \mathrm{L}$ & \\
\hline 19 & Zingiberine & -4.13 & $933.32 \mu \mathrm{mol} / \mathrm{L}$ & \\
\hline 20 & (E)-dodec-2-en-1-ol & -3.16 & $4.86 \mathrm{mmol} / \mathrm{L}$ & \multirow{2}{*}{ Coriandrum sativum } \\
\hline 21 & Methyl hexadecanoate & -1.91 & $39.90 \mathrm{mmol} / \mathrm{L}$ & \\
\hline 22 & Eugeniin & Not active & - & \multirow{2}{*}{ Syzygium aromaticum } \\
\hline 23 & Isobiflorin & -5.57 & $83.04 \mu \mathrm{mol} / \mathrm{L}$ & \\
\hline 24 & $\gamma$-Terpinene & -3.86 & $1.49 \mathrm{mmol} / \mathrm{L}$ & \multirow{2}{*}{ Trachyaspermum ammi } \\
\hline 25 & Lingustilide & -4.93 & $245.31 \mu \mathrm{mol} / \mathrm{L}$ & \\
\hline 26 & (E)-3,7,11,15-tetramethylhexadec-2-en-1-ol & -2.4 & $17.38 \mathrm{mmol} / \mathrm{L}$ & Mentha arvensis \\
\hline
\end{tabular}

interface of Ayurveda and in silico biology. The reported result in this article (Table 1) is an Ayurveda phytoconstituents in silico efforts study which further necessitates the need for pre-clinical and clinical research of the active compounds (Figure 1) to increase the understanding in the development of effective future therapeutics in Ayurveda.

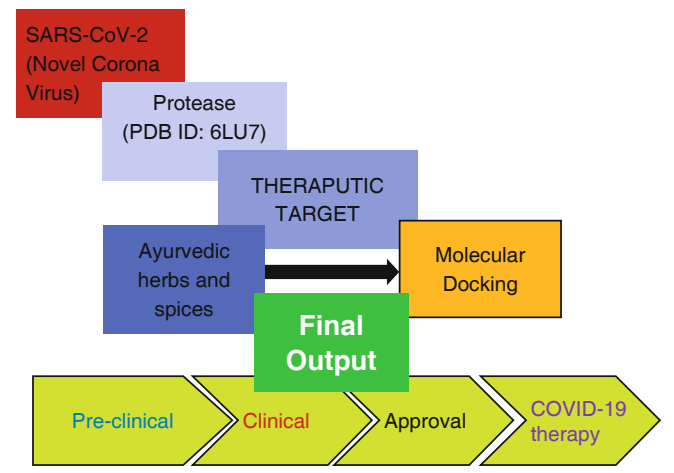

Figure 1. Roadmap of Promising Antiviral Molecules Identification from Ayurvedic Herbs and Spices for COVID-19 Therapy

\section{Acknowledgments}

Authors thank the Madurai Kamaraj University, Madurai (TN); Shri NPA Government Ayurveda College, Raipur (CG); and National Institute of Technology, Raipur (CG), India for continuous support and assistance for research work and scientific writing.

\section{Conflict of Interest}

None.

\section{REFERENCES}

1. Upreti S, Prusty JS, Pandey SC, Kumar A, Samant M. Identification of novel inhibitors of angiotensin-converting enzyme 2 (ACE-2) receptor from Urtica dioica to combat coronavirus disease 2019 (COVID-19). Mol Diver 2021;24:1367-1383.

2. Luo H, Gao Y, Zou J, Zhang SY, Chen HB, Liu Q, et al. Reflections on treatment of COVID-19 with traditional Chinese medicine. Chin Med 2020;15:94.

3. Wang JB, Wang ZX, Jing J, Zhao P, Dong JH, Zhou YF, et al. Exploring an integrative therapy for treating COVID-19: a randomized controlled trial. Chin J Integr Med 2020;26:648-655.

4. Bruno A, Costantino G, Sartori L, Radi M. The in silico drug discovery toolbox: applications in lead discovery and optimization. Curr Med Chem 2019;26:3838-3873.

5. Vimal A, Kumar A. Spices chemoconstituents as persuasive inhibitor of $S$. typhimurium virulent protein L-asparaginase. Drug Design Discov 2017; 14:1433-1454.

6. Seth S, Batra J, Srinivasan S. COVID-19: targeting proteases in viral invasion and host immune response. Front Mol Biosci 2020;7:215.

7. Maurya VK, Kumar S, Prasad AK, Bhatt MLB, Saxena SK. Structure-based drug designing for potential antiviral activity of selected natural products from Ayurveda against SARS-CoV-2 spike glycoprotein and its cellular receptor. Virus Dis 2020;31:179-193.

8. Vázquez-Fresno R, Rosana ARR, Sajed T, Onookome-Okome T, Wishart NA, Wishart DS. Herbs and spices-biomarkers of intake based on human intervention studies-a systematic review. Genes Nutr 2019;14:18.

(Accepted December 25, 2020; First Online February 5, 2021) Edited by YU Ming-zhu 